\title{
THE
}

\section{Specialized Literacy Professionals as Literacy Leaders: Results of a National Survey}

Rita M. Bean

Diane Kern

University of Rhode Island, dkern@uri.edu

Virginia Goatley

Evan Ortlieb

Jennifer Shettel

Follow this and additional works at: https://digitalcommons.uri.edu/education_facpubs

\section{The University of Rhode Island Faculty have made this article openly available.} Please let us know how Open Access to this research benefits you.

This is a pre-publication author manuscript of the final, published article.

Terms of Use

This article is made available under the terms and conditions applicable towards Open Access Policy Articles, as set forth in our Terms of Use.

\section{Citation/Publisher Attribution}

Bean, R., Kern, D., Goatley, V., Ortlieb, E., Shettel, J., Calo, K., Marinak, B., Sturtevant, E., Elish-Piper, L., L'Allier, S., Lane, M., Frost, S., Mason, P., Quatroche, D., Cassidy, J. (2015). Specialized literacy professionals as literacy leaders: Results of a national survey. Literacy Research and Instruction, Taylor \& Francis, 1-32, DOI 10.1080/19388071.2014.998355.

Available at: https://doi.org/10.1080/19388071.2014.998355 


\section{Authors}

Rita M. Bean, Diane Kern, Virginia Goatley, Evan Ortlieb, Jennifer Shettel, Kristine Calo, Barbara Marinak, Elizabeth Sturtevant, Laurie Elish-Piper, Susan L'Allier, Mae A. Cox, Shari Frost, Pamela Mason, Diane Quatroche, and Jack Cassidy 
Specialized Literacy Professionals as Literacy Leaders: Results of a National Survey by

Rita M. Bean, University of Pittsburgh Diane Kern, University of Rhode Island Virginia Goatley, University at Albany Evan Ortlieb, MOnash University Jennifer Shettel, Millersville University of PA Kristine Calo, Johns Hopkins University Barbara Marinak, Mount St. Mary's University Elizabeth Sturtevant, George Mason University Laurie Elish-Piper, Northern Illinois University Susan L'Allier, Northern Illinois University Mae Lane, Sam Houston State University Shari Frost, Blitstein Teacher Institute of Hebrew Theological College Pamela Mason, Harvard University Diana Quatroche, Indiana State University Jack Cassidy, Texas A \& M-Corpus Christi 
Specialized Literacy Professionals as Literacy Leaders

\begin{abstract}
This large-scale national survey of specialized literacy professionals was designed to answer questions about responsibilities, including leadership, and about preparation for these roles. Questionnaires, completed by over 2,500 respondents, indicated that respondents had multiple responsibilities that included both instruction of struggling readers and support for teachers. Four distinct role-groups were identified: instructional/literacy coaches, reading/literacy specialists, reading teachers/interventionists, and supervisors. The findings indicated a need for more precise definitions of the roles of these professionals and for preparation programs to include experiences that address the tasks required. Themes discussed included: roles have changed and require more focus on leadership, specialists need to be nimble, and they require more in-depth preparation if they are to be able to handle the leadership demands of their positions.
\end{abstract}


Specialized Literacy Professionals as Literacy Leaders

\section{Specialized Literacy Professionals as Literacy Leaders: Results of a National Survey}

Over time, the role of reading specialists has evolved and continues to do so (Bean, Cassidy, Grumet, Shelton, \& Wallis, 2002; Bean, Swan, \& Knaub, 2003; Briggs and Coulter, 1977; Dole, 2004; Kern, 2011; Stauffer, 1967). Some changes occurred because of shifts in Title 1, which provided funding for many reading specialists (Borman, Stringfield, \& Slavin, 2001). In the early 2000s, Reading First, the programmatic arm of the No Child Left Behind Public Act of 2001 (NCLB, 2001), generated the hiring of reading coaches to work with teachers to improve classroom literacy instruction. Reading specialists often found themselves in this newly defined position. Other changes have occurred because of Response to Intervention (RtI) with its focus on providing multi-tiered instruction (Bean \& Lillenstein, 2012). Reading specialists found themselves in the role of interventionists, working with struggling readers who needed supplemental or targeted instruction. More recently, reductions in federal, state, or local funding have eliminated positions or required shifts in responsibilities for many reading specialists or literacy coaches (Steinbacher-Reed \& Powers, 2011/2012).

Given these changes, there is a need to learn more about how specialized literacy professionals (e.g., reading specialists, literacy coaches, instructional coaches, interventionists) actually function in schools, how prepared they are to assume their roles, and what skill sets are important to their success. Further, information about the role of these specialized literacy personnel as school leaders who influence school reform and improvement (Galloway \& Lesaux, 2014) can provide ideas useful to those who function in such roles. The purpose of this study, then, is to inform those who prepare and employ specialized literacy professionals about how these professionals function in schools and the challenges they face. Such information can lead to improvements in specialized literacy personnel preparation programs and, in addition, assist 
school districts in better understanding the role of such personnel and establishing school contexts necessary for these professionals to work effectively. Results may also provide insights into how specialized literacy professionals contribute to improving teacher practices and student learning.

In this article, we addressed the following research questions: (1) What are the current roles and responsibilities of specialized literacy professionals? (2) In what ways do specialized literacy professionals engage in leadership activities? (3) What do these specialized literacy professionals believe would have prepared them to function more effectively in their roles? First, we provide background information about the roles of specialized literacy professionals and then briefly discuss shared leadership as a theoretical framework for this study. Next, we describe the methods of the study and summarize the results. Last, we conclude with a discussion of findings and implications for specialized literacy professionals, those responsible for preparing or employing them, and for policymakers (e.g., professional organizations, states).

\section{Background Information}

In the late 1990s, the International Reading Association (IRA) established a commission to obtain empirical evidence that would assist in the development of a position statement on the role of the reading specialist in schools. Results of a survey distributed nationally and completed by 1,512 respondents identified four major functions of reading specialists: providing instruction, assessing student performance, serving as a resource, and handling administrative tasks (Bean, et al., 2002). Over $90 \%$ of the respondents indicated their primary task was that of instructing students, with more than $75 \%$ of their day spent in this role. Over $84 \%$ of the respondents indicated they served as a resource to teachers by providing materials, ideas, and support. Respondents identified how their role had changed as a result of trends in reading instruction. 
For example, the national instructional shift from a pull-out to an in-class model of instruction resulted in teachers viewing reading specialists as both a resource and a school leader who could provide professional development on instructional issues. However, there was no mention of literacy coaches or coaching in this study (Bean, et al., 2002).

As indicated previously, a major initiative that had a dramatic impact on the role of the reading specialist was that of Reading First (NCLB, 2001). Schools that participated in the Reading First initiative were required to provide on-going, job-embedded professional development (PD) for their teachers. Most often, that PD was led by reading coaches, which 99\% of the Reading First schools employed during the multiple years of Reading First (U.S. Department of Education, 2008). Many states and professional organizations identified guidelines to assist schools in making decisions about hiring coaches, for example, hiring individuals who had a deep knowledge and understanding of "literacy processes, acquisition, assessment, and instruction" (International Reading Association, 2004). According to Frost and Bean (2006), the "gold standard" for a literacy coach was that the individual possessed a reading specialist certificate, was an experienced classroom teacher, and had leadership and coaching skills.

In an analysis of the evaluations conducted in Reading First schools in 11 states, Bright and Hensley (2010) found reading coaches tended to be teachers with 11 to 19 years of experience who possessed graduate degrees and had advanced literacy training. However, the advanced degrees were not necessarily in the literacy area and the percentage of individuals possessing reading specialist or reading endorsement certificates ranged from as low as $16 \%$ in Arkansas to as high as $80 \%$ in Illinois. According to Carroll (2007), when reading specialists 
were reassigned and asked to serve as reading coaches in their schools, many of these professionals learned how to function as coaches "on the job."

In other words, literacy coaching was implemented with limited empirical evidence about the qualifications coaches needed to perform effectively or how they should function in schools. As stated by Snow, Ippolito, and Schwartz (2006), “.... Like many good ideas in education, literacy coaching is being widely implemented based on its convergence with theory and the wisdom of practitioners, before rigorous evaluations have been carried out" (p. 36). Since that time, numerous studies provide evidence about the role of coaches in schools (Bean, Draper, Hall, Vandermolen, \& Zigmond, 2010; Coburn \& Woulfin, 2012; Grierson, 2011; Ippolito, 2010; Scott, Cortina, \& Carlisle, 2012; Vanderburg \& Stephens, 2010) and the impact of coaching on teacher practices and student learning (Bean \& Lillenstein, 2010; Biancarosa, Bryk, \& Dexter, 2010; Elish-Piper \& L'Allier, 2010; Elish-Piper \& L'Allier, 2011; Matsumura, Garnier, Correnti, Junker, \& Bickel, 2010; Powell, Diamond, \& Koehler, 2011).

In 2010, IRA released its revised set of Standards for Reading Professionals, including reading specialists/literacy coaches. In these standards, reading specialist/literacy coach was used as an overarching title, and three possible roles, or combination of roles, were described: "serving as a teacher for students experiencing reading difficulties, as a reading or literacy coach, as a coordinator of reading and writing programs at the school or district level (p. 49). As stipulated in the IRA Standards for Reading Professionals document, all those enrolled in reading specialist programs are expected to develop leadership skills (including coaching) as a means of handling their dual responsibilities of teaching struggling readers and supporting the work of the classroom teachers. Coaching activities were embedded in the competencies for the reading specialist/literacy coach, describing three levels of responsibilities: candidates "can do, can 
Specialized Literacy Professionals as Literacy Leaders

support (teachers), and can lead” (p. 68). Recently, Galloway and Lesaux (2014) synthesized research about the roles assumed by reading specialists. They identified three key themes related to the roles of these specialized literacy professionals: (1) specialists fill multiple roles and they experience varying levels of comfort with these roles, (2) different stakeholders view these roles differently, and (3) context influences how they carry out these roles. Galloway and Lesaux concluded there was a need for a large-scale national study to provide the field with a deeper understanding of how specialized literacy professionals currently spend their time in schools. This article summarizes the results of such a national study.

\section{Theoretical Perspective}

No longer is leadership in schools interpreted as the domain or responsibility of one individual (e.g., the principal); rather shared leadership, defined as "learning together, and constructing meaning and knowledge collectively and collaboratively," is being seen as essential for promoting overall school improvement (Lambert, p. 5). Such leadership recognizes the importance of building school capacity by encouraging classroom teachers and those with specialized roles (e.g., reading specialist, literacy coach) to participate in improving the organization. It calls for creating a culture of collaboration (Elmore, 2000; Camburn, Kimball, \& Lowenhaupt, 2008; Leithwood \& Jantzi, 2008), one in which those in positions of authority establish conditions that support the leadership work of others in the school. As discussed by Bryk, Sebring, Allensworth, Luppescu, and Easton (2010) in their study of reform in Chicago Public Schools, the leadership of the principal is essential for school success, but it is not sufficient - teacher leadership and engagement in school change efforts are also important. Taylor, Pearson, Peterson, and Rodriguez (2005) in their study of change in school literacy learning, found that teachers who worked collaboratively to address instructional issues in 
schools were identified as high implementers of the program. They also found that shared leadership and job-embedded professional development were essential in creating a culture which included a common vision of learning, literacy, and high expectations for students. Taylor et al. (2005) also indicated that typically there was one strong teacher leader who led the change effort in the school. Camburn, Rowan, and Taylor (2003), found that leadership responsibility was shared among several individuals in school reform efforts, and often one of the leaders was a literacy specialist (e.g., a reading specialist, coach). Supovitz, Sirinides, and May (2010) also found that although principal leadership was critical, peers also influenced teachers' practices by talking with them, coaching, and providing specific advice about assessment and instruction.

With this movement towards shared leadership comes a need for developing teachers' abilities to function as leaders and as members of a learning community. In a study of five elementary schools involved in implementing Response to Intervention (Bean \& Lillenstein, 2010), leadership was distributed among many of the personnel in the buildings; further, reading specialists and coaches had key roles in leading and facilitating implementation efforts. Most frequently, these specialized literacy professionals worked as a team to support teachers and help them understand how to use student data and to provide differentiated instruction. Although the leadership role of specialized literacy professionals tended to be an informal one, based on influence rather than authority (Coburn \& Woulfin, 2012), these literacy professionals were greatly involved in leadership activities. They helped teachers understand and use student data, provided them with instructional ideas and job-embedded professional development, coached them, and helped them improve their classroom instructional practices.

\section{Research Design}


The research design described below was developed to address the purpose of the study, specifically, to inform those who prepare and employ specialized literacy professionals about how these professionals function in schools and the challenges they face. In this section, we provide a context for the research design, describe the sampling selection and respondents, and discuss approaches for analyzing data.

\section{Context}

Several years ago, leaders of the Specialized Literacy Professionals Special Interest Group of IRA (SLP-SIG) invited the authors of this study to join a committee charged with obtaining information about the current roles of specialized literacy professionals, especially reading specialists and literacy coaches. These authors were involved in developing the research design, which included revising the survey used in a previous study (Bean et al., 2002). Development of the survey began with a review of the initial survey; however, changes were made to accommodate current emphases in the role of specialized literacy professionals (e.g., adding questions about the coaching role). The final survey elicited quantitative information from respondents about their roles and responsibilities; it also included several open-ended questions about quality of preparation, positive aspects of the role, major challenges, and factors that would enable professionals to be more successful in their roles. (In this paper, we focus on the quantitative questions and a single open-ended question on quality of preparation). Before distribution, a field test of the survey was conducted with 22 reading specialists/literacy coaches from different states. The final survey consisted of 46 items that were formatted and prepared for distribution via SurveyMonkey (www.surveymonkey.com). (See Appendix A for a copy of the survey). These researchers, supported by SLP-SIG, received approval from both the IRA 
Specialized Literacy Professionals as Literacy Leaders

and National Council of Teachers of English (NCTE) to distribute the survey using their websites and listserv capabilities.

\section{Sample Selection}

The IRA sent email messages to all members who had self-identified as reading specialists/literacy coaches, or who did not identify any job title, and also posted a notice about the survey on its website, Facebook page, and Twitter. Likewise, NCTE distributed an email to members and posted a notice on its website. The email messages encouraged receivers to forward the survey to colleagues who also served in such roles, indicating it was not necessary for respondents to be members of either organization. In other words, snowball sampling (Nardi, 2003), a convenience sampling technique in which research participants are asked to assist in the identification of other subjects, was used to increase size and variability (respondents representing various grade levels and role groups) of the sample, and obtain responses from specialized literacy professionals who were not members of either IRA or NCTE. The link to the SurveyMonkey website was kept open for 30 days.

\section{Respondents}

After eliminating ineligible respondents (i.e., principals, classroom teachers, or university faculty not serving as specialized literacy professionals), the final number of respondents was 2,531. All states were represented, as were the United States territories of American Samoa, Guam, Northern Marianas Islands, Puerto Rico, and Virgin Islands. The majority of respondents who answered questions about ethnicity and gender were Caucasian (90\%) and female (97\%). Of those responding, most held an undergraduate degree in elementary education (63\%), a small percentage majored in secondary education $(9 \%)$ or in special education $(5 \%)$, and $22 \%$ indicated "other". Only 6\% indicated they had taught less than one year or not at all; over 31\% 
had taught 11 years or more and $29 \%$ had worked as a classroom teacher for at least 6 to 10 years before taking a position as a specialized literacy professional. The demographics for each of the role-groups were similar to those of the group as a whole.

Almost all respondents worked in public schools (92\%) in a full-time position (92\%). Most individuals in this study worked in one school (78\%), with $12 \%$ working in two to four schools, and $9 \%$ in five or more schools. Only $31 \%$ worked in schools with no other specialized literacy professionals; $40 \%$ had one to two additional specialized literacy professional colleagues and the remainder worked in schools with three or more specialized literacy professionals. As a whole, $52 \%$ of the respondents served at the elementary level, $21 \%$ had positions at the secondary level, and $6 \%$ worked at both levels. The other respondents worked in some combination of grade levels (e.g., from K-grade 12, preschool only).

\section{Data Analysis}

Defining the role. To develop the survey options for the question "What is your job title?" the researchers used the pilot survey, current state certification titles, and professional literature (e.g., Bean, 2009; Coburn \& Woulfin, 2012) that suggested multiple job titles associated with literacy professionals. To be inclusive, respondents were able to choose from 11 different job titles to identify themselves, or to click the "other" box and write a specific job title. To make sense of this large data set, a subset of authors (Ortlieb, Goatley, Bean, \& Lane) analyzed the data as a means of identifying role-groups that could then be used as a basis for analyzing responses to other items on the survey. These authors coded for words or patterns (Palmquist, Carley, \& Dale, 1997) by analyzing and collapsing across all job titles, including the “other" category. To substantiate the categorization system, responses to two survey questions were analyzed: (1) Which of these best describes your primary responsibility? (2) How would 
you describe your role? These analyses led to the identification of four role-groups: instructional/literacy coaches $(\mathrm{n}=774)$, reading teachers/interventionists $(\mathrm{n}=707)$, reading/literacy specialists $(n=898)$, and supervisors $(n=142)$. We then calculated chi-square analyses for the responses to the two questions above. There were significant differences in the distribution of responses among four role-groups in how they described their primary responsibility [Chi-Square $(9, N=2221)=1250, p=<.0001]$ and also in describing their role [Chi-Square $(9, N=2245)=761.2, p=<.0001]$, indicating that the individuals in these four groups did differ in their perceptions of how they functioned in schools. Ten respondents did not identify themselves by title; their responses were not included in any analysis by job titles, although they are included in responses to other items on the survey. When respondents are referred to as a whole, we refer to them as specialized literacy professionals to reflect (a) their advanced preparation, and (b) the specialized nature of their responsibilities (e.g., working with struggling readers, supporting teacher learning).

Quantitative analysis. Quantitative analysis consisted of calculating frequency distributions for responses to Likert-scale items; when appropriate, cross tabulations were conducted to determine whether there were differences in how the various role-groups responded to specific items. Percentages calculated for specific items were based on different totals, given not all respondents answered all questions; these differences are noted in the tables in this article.

Qualitative analysis. In addition to the quantitative analysis of the closed-item questions, we analyzed the results of one open-ended question, "What would have prepared you to be successful in your role?" We used the NVivo software program (2010) to code data for each of the four roles, capturing key words and phrases directly from the raw data. Next, we looked at the patterns in the data to create pattern codes (e.g., need for more coaching 
Specialized Literacy Professionals as Literacy Leaders

experiences, more strategies for working with struggling readers). Two authors then categorized responses of the groups as belonging to one of the six standards identified in the Standards for Preparing Reading Professionals (IRA, 2010). For example, if a respondent identified the need to know more about working with English Learners, that response was coded as the need to know more about diversity (IRA Standard 4). To establish interrater reliability, these two authors independently categorized the responses of 100 respondents to the question about preparation and found a greater than $90 \%$ agreement in their coding of responses.

\section{Results}

In this section, we present results for each of the three research questions.

\section{What are the Current Roles and Responsibilities of Specialized Literacy Professionals?}

We first discuss the responses to the question in which we asked respondents to describe their primary responsibility as a whole and then by role-group (see Table 1). Almost $46 \%$ of respondents indicated their primary responsibility was that of working with students who are experiencing difficulty with reading, followed by $28 \%$ of the respondents who indicated they had coaching responsibilities. Almost one quarter $(23 \%)$ of the respondents had multiple and equal responsibilities while only a small percent (3\%) identified themselves as serving as coordinators of the literacy program.

When analyzing responses to the question about primary responsibility across rolegroups, there were major differences. Almost $70 \%$ of the coaches identified their primary responsibility as coaching; few of the coaches listed working with students as a major responsibility. Almost $73 \%$ of the reading teachers/interventionists, on the other hand, indicated their primary responsibility was working with students. Similar to the reading teachers/interventionists, about two-thirds $(67 \%)$ of the reading/literacy specialists indicated they 
worked with students but this was followed by multiple responsibilities (26\%). Only 108 individuals identified as supervisors answered this question and almost half of those (44\%) responded they had multiple responsibilities while one-third (32\%) had primarily coaching responsibilities.

\section{*****Insert Table 1 about here ${ }^{* * * * * *}$}

Tasks. In Table 2, we illustrate the rankings of the five activities (of a possible 18) most frequently performed for the group as a whole and also across the four role-groups. We assigned a different weight to the possible responses [e.g., not at all (0), a little (1), somewhat (2), and great deal (3)] to determine the ranking. The group as a whole ranked "instructing" as the task on which they spent most of their time, but this was affected by the large numbers of reading teachers/interventionists and reading/literacy specialists in the sample. An important similarity among role-groups is that all of them ranked "supporting teachers" as one of their five major tasks. But we also saw differences in the rankings of the role-groups. Like the other groups, instructional/literacy coaches spent time supporting teachers with materials and resources, but they were the only role-group that identified "coaching" as one of the five major tasks. Neither coaches nor supervisors ranked assessing or instructing students as one of the top five, unlike reading/literacy specialists and the reading teachers/interventionists who ranked both these tasks in the top five. Supervisors' rankings were similar to coaches in that they worked with leadership teams and facilitated teacher groups; they were the only group to identify the task "conducting workshops," in their top five. The four tasks in which $80 \%$ or more of the respondents spent little or no time were: grant writing, preparing or supporting the work of paraprofessionals, working with communities of practice, and spending time with non-reading related tasks, such as substituting for other teachers or handling administrative responsibilities. 
In sum, the responses to the research question about the roles of the specialized literacy professional indicated that responsibilities of the specialized literacy professional varied, not only across role-groups, but also within the role-group itself. Moreover, regardless of rolegroup, most had multiple tasks and responsibilities. However, it also appears that those identified as coaches had responsibilities similar to those who identified themselves as supervisors, while the reading/literacy specialists' tasks were more similar to those of the reading teachers/interventionists. Regardless of role-group, almost all spent time supporting teachers.

******Insert Table 2 about here ${ }^{* * * * * *}$

\section{In What Ways Do Specialized Literacy Professionals Engage in Leadership Activities?}

Leadership tasks. Respondents were asked to select one of five choices that best described their role in supporting teachers (See Table 3). Almost all (89\%) who responded to this question spent some time supporting the work of teachers. About $25 \%$ of those who selfidentified as a coach indicated working with teachers was their major responsibility; other coaches (19\%) spent half of their time supporting teachers. The remaining respondents (45\%), who did not identify themselves as coaches, viewed themselves as having either a major role in supporting teachers or working with teachers informally.

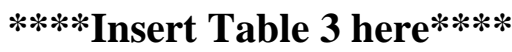

We also asked respondents to indicate the types of coaching and other leadership activities in which they engaged and the extent to which they emphasized those activities (e.g., from not at all to a great deal). As illustrated in Table 4, a lower percentage of reading/literacy specialists and reading teachers/interventionists than coaches and supervisors indicated they spent a "great deal of time" on these activities. For example, over $50 \%$ of coaches spent a great deal of time in five different coaching activities: conferring, observing, planning, conducting 
workshops and modeling. This is similar to the responses of supervisors except that the supervisors spent a great deal of time facilitating professional learning communities rather than planning with teachers. On the other hand, reading teachers/interventionists and reading/literacy specialists performed various coaching activities, but fewer respondents (between 24\% and 42\%) identified these activities as ones on which they spent a great deal of time. All role-groups spent time conferring with teachers about identified problems and all but the supervisors highlighted time spent planning with teachers. All role-groups except reading/literacy specialists identified observing and providing feedback as activities on which they spent time. The only two rolegroups that identified "serving on an RtI" team as a coaching activity on which they spent a great deal of time were reading teachers/interventionists and reading/literacy specialists. These data indicate that groups were providing similar sorts of support to teachers, although as evident in Table 4, more emphasis was placed on these activities by a greater percentage of coaches and supervisors than reading teachers/interventionists and reading/literacy specialists.

****Insert Table 4 about here****

Importance of school culture and collaboration. Because of the influence of school culture on specialized reading personnel's roles and responsibilities (Galloway \& Lesaux, 2014), we asked several questions about both school climate and the existence of professional learning communities. About one third of the respondents indicated that, to a great extent, there was a common vision in their school, teachers enjoyed working with and helping each other, students showed respect for teachers, and principal leadership was evident. Many of these respondents (44\%) also indicated their schools, to a great extent, had high expectations for students.

We then asked respondents to indicate whether their school exhibited features of professional learning communities, using characteristics identified by Vescio, Ross, and Adams 
(2008). The most highly rated feature, coded as existing to a great extent, was the focus on student learning $(60 \%)$, while the two lowest rated features were "teaching is made public" (24\%) and "opportunities exist for reflective dialogue" (31\%). Only 34\% of respondents indicated that, to a great extent, there were shared values in the school or opportunities for collaboration existed (40\%).

The importance of administrative leadership and support were seen as keys to the success of the specialized literacy professional; as one respondent stated, "the principal needs to be a leader of learning and have a vision which is used to focus and energize the school." Respondents saw collaboration among teachers as essential, with "planned collaboration time integrated into teachers' schedules... and time to collaborate with my coaching colleagues." A comment by one respondent summarizes the importance of the school culture: "a defined role with expectations for me and staff, a framework for collaboration (we have professional learning communities, but [they] do not function effectively); opportunities to continue to learn (attend workshops, meet with other coaches), better school climate-leadership, trust, common goals."

The importance of collaboration and coordination of reading instruction across various programs (e.g., classroom, special education, Title 1, RtI) is also reflected in the findings that only $7 \%$ of the respondents in this study indicated they were the students' sole reading teacher. Frequently, students with whom they worked also received reading instruction from classroom teachers, reading specialists, special educators, paraprofessionals, or volunteers.

What Preparation Have Specialized Literacy Professionals Received? What Do They Need to be Successful in Their Roles?

Most specialized literacy professionals had graduate or advanced preparation, but not necessarily reading-related: $75 \%$ of survey respondents held a Master's degree, with 55\% of 
those degrees being listed as Reading Education; 53\% were certified as reading specialists. Respondents were asked to identify all organizations in which they held memberships. Most respondents $(90 \%)$ indicated they belonged to at least one professional organization; $56 \%$ were members of the International Reading Association (IRA), 30\% belonged to their state reading association, and $28 \%$ were active in the local reading association. Also, $20 \%$ of respondents indicated they were members of the National Education Association, and $10 \%$ were members of the National Council of Teachers of English. Respondents were also asked, in an open-ended question, to indicate what preparation might have helped them be more successful in their roles. Approximately 56\% ( $\mathrm{n}=1,407)$ of the survey respondents provided answers to this question; many provided more than one response and all role-groups were represented. We categorized the 1,626 responses into one of the six standards described in the Standards for Preparing Reading Professionals - Revised (IRA, 2010) (see Table 5). Overwhelmingly, respondents from all role-groups described a need for a wide variety of experiences that would enable them to more effectively address their leadership role (Standard 6: Leadership and Lifelong Learning).

\section{*****Insert Table 5 about here ${ }^{* * * * *}$}

We then conducted a more in-depth qualitative analysis of responses and found respondents overall identified the need for more learning experiences related to working with adults and leadership. Many respondents indicated they would have been better prepared if they had: (a) earned an advanced degree in literacy education prior to starting the position; (b) been involved in a supervised field experience while in that program; and, (c) coaching experiences in school settings. As one respondent stated, "this position should require a master's degree in reading....after obtaining the reading specialist training, it was much easier." In fact, between $11 \%$ (interventionists/reading teachers) to $33 \%$ (instructional/literacy coaches) of the 
respondents in the role-groups indicated they were better prepared because of advanced work that included coaching. Several respondents expressed a desire for "more courses in coaching or more opportunities to hone my coaching skills." Some specialized literacy professionals suggested that a supervised experience with those serving as literacy coaches would be helpful in learning how to coach. As one respondent wrote, one must "shadow an effective reading coach to see how he/she goes about planning a day, meeting with teachers, facing challenges." Nearly $60 \%$ of respondents identified as instructional/literacy coaches and reading/literacy specialists called for a semester or year-long supervised school-based experience working with a master teacher serving in the role of a coach; a smaller percentage of reading teachers/interventionists (30\%) and supervisors (5\%) suggested supervised clinical coaching experience. Respondents also made other suggestions: "I would have liked to have been coached by a coach and have reflective time with other coaches;" "the internship our state provides would have been more beneficial at the beginning of the year than in February;" and as one professional called it, "onthe-job student teaching" with a coach. In sum, respondents called for more coaching experiences in certification programs, additional readings, and discussion about topics such as adult learning theory, coaching, and literacy leadership.

Respondents also valued ongoing, on-the-job professional development as a means of improving their leadership and coaching abilities. Specialized literacy professionals new to the position desired experiences that would increase their ability to work with teachers (e.g., "I need to learn how to move people to the next rung of their ladder, motivating and providing leadership to people who are stuck or content with the status quo"). Over $90 \%$ of respondents in the role of instructional/literacy coach and $65 \%$ of respondents identified as reading or literacy specialists stated they needed more coaching experiences during the first year in their positions while 
Specialized Literacy Professionals as Literacy Leaders

smaller percentages of reading teachers/interventionists (26\%) and supervisors (7\%) saw this as a need. One respondent stated, "Any coaching training would have been helpful I learned to coach by contacting other coaches in the districts myself and arranging meetings and observations." Many respondents noted the importance of understanding adult learning theory and specific best practices for working with adult learners; or as one respondent stated, "I need more training on creating buy-in with teachers as well as coaching language." Finally, respondents indicated they often were the source of professional learning for others, but did not have sufficient opportunities to continue their own learning. The greatest need as identified by all respondents, regardless of role, was having a better sense of how to work with other adults to collaboratively improve instruction and student learning, that is, to function as leaders in their schools.

\section{Discussion}

This discussion focuses on five themes derived from the results of quantitative and qualitative data analysis. They address issues engendered by survey responses, and organized around the research questions about roles and responsibilities, leadership, and preparation of specialized literacy professionals. The five themes include changes in role, variability in role, leadership as a key aspect of the role, importance of being nimble, and need for additional preparation.

\section{Changes Have Occurred in Roles, Responsibilities, and Titles}

One of the major differences in the results of this study as compared to those reported in the 2002 survey is that of coaching or coaches. The addition of coaching to the role responsibilities of specialized literacy professionals is also seen in the questionnaires distributed by the U.S. Department of Education in its Schools and Staffing Questionnaires (USDE, 2004, 2007-2008; USDE, 2011-2012). In the 2004 questionnaire, only the term reading specialist was 
used; in the 2007-2008 questionnaires, schools were asked whether they had reading specialists and/or reading coaches in their schools; in the 2011-2012 questionnaire, instructional coach was introduced as one of the possible choices. These later questionnaires included a definition that distinguished between the role of specialist and coach, (e.g., specialists worked with students and coaches worked with teachers). It appears as though titles describing various positions of specialized literacy professionals have been influenced by specific educational reforms. Response to Intervention, for example, generated a new title for reading specialists who serve as “interventionists." The emphasis on improving classroom literacy during Reading First led to the use of the title reading or literacy coach.

Another difference between the findings of the 2002 study and the current study was the number of respondents holding reading specialist certification: Approximately $90 \%$ of the respondents in 2002 held reading specialist certification as compared to $53 \%$ overall in the current study (Figure 1 displays comparisons of results of the 2002 and current study). Moreover, only $19 \%$ of the reading/literacy coaches in this study held specialist certification. Also, fewer respondents (56\%) in the current study were members of IRA or NCTE, indicating the "snowball sampling" approach was successful in recruiting respondents who were not members of either association.

In the current study, we saw differences in the assessment responsibilities of coaches and supervisors as compared to reading teachers/interventionists and reading/literacy specialists. The coaches and supervisors ranked "analysis of data" as one of the five tasks on which they spent much of their time, but administering assessments was not in that list. Reading teachers/interventionists and reading/literacy specialists, on the other hand, ranked both the administration of assessment instruments and analyzing data in their list of tasks on which they 
spent most of their time. The current emphasis on assessment, especially classroom and school level data, as essential for instructional decision-making and for accountability has appeared to influence the work of these specialized literacy professionals.

Over $84 \%$ of the respondents in the 2002 study had resource responsibilities that included supporting teachers in their instructional efforts (e.g., providing teachers with materials and ideas, especially for struggling readers). Likewise, in the current study, $89 \%$ indicated they had some responsibility for supporting teachers, requiring them to serve as leaders and work collaboratively with adults. It appears as though reading specialists have always had some responsibility for supporting teachers, but now such support seems to extend beyond "providing ideas and materials" to include helping teachers improve their classroom instruction and using data to inform instruction, not only in a single classroom but at a grade level or in a school.

Some similarities exist between the findings of the 2002 study and the present one. Again, there was little demographic diversity in respondents (e.g., primarily female). Moreover, there was not much of a difference in the percentage of respondents overall at the secondary level. However, in the current study, over a third (39\%) of those in the coach role-group worked at the secondary level or with both elementary and secondary levels. In other words, more of the respondents at the secondary level had responsibilities for working with teachers to improve instruction rather than providing direct instruction to students.

Instruction was still an important responsibility for the specialized literacy professional. In the current study, over $75 \%$ of the respondents had some sort of instructional role and most of that work was with readers experiencing difficulties (98\%); likewise, in the 2002 study, over $90 \%$ of the reading specialists indicated that they instructed on a daily basis.

\section{Specialized Literacy Professionals Serve Many Different Roles}


In the current study, specific titles did enable us to differentiate between and among roles more precisely with instructional/literacy coaches tending to have responsibilities for working with teachers, and reading teachers/interventionists being responsible for providing instruction to struggling readers. Also, supervisors tended to perform more like coaches. Those who selfidentified as reading specialists were the most diverse in terms of role expectations, with responsibilities ranging from working primarily with students to working as coaches or even as coordinators (see Figure 2, for a summary of how these four role-groups differed, in general, and also in the emphases given to tasks and responsibilities). It appears as though some school districts that employ these specialized literacy professionals, by using specific titles, do make distinctions across roles. Nevertheless, these distinctions are not clear-cut and no single or simple definition fits any one of the sub-groups. As stated by Galloway and Lesaux (2014), reading specialists may assume many different roles (e.g., student-oriented, data-oriented, teacher-oriented, and managerial). One can imagine then the difficulty for these professionals, especially if ambiguity or divergent perceptions surround the expectations of the role by school leadership, teachers, or even the individual in the position.

\section{Leadership Is an Integral Aspect of Any Specialized Literacy Professional Role}

Many types of leadership activities were evident in this study requiring professionals to work effectively with other adults. Almost all respondents provided informal support (e.g., providing teachers with ideas and materials, assisting them with interpreting data, or making instructional decisions). Others had more formal leadership roles (e.g., coaching, developing curriculum). Moreover, two thirds of the respondents indicated they worked with other specialized literacy professionals in their schools, requiring them to work collaboratively with them as well as with teachers. Also, many of these specialized literacy professionals were not the sole literacy 
instructor for students; therefore, they had to work collaboratively with classroom teachers to make decisions about how to plan and schedule instruction. In other words, respondents worked in situations that required shared leadership, participation in decision-making at the school and district level, and collaboration to achieve a common vision and goals.

\section{Specialized Literacy Professionals Must Be Nimble}

Schools, like other organizations, change over time; they are affected by internal (e.g., leadership, test scores, curricular or demographic) and external (state or federal requirements, societal) conditions. And like any organization, schools need to adapt to address these challenges. Adaptation requires those within the organization to be nimble, that is, be able to move quickly, but thoughtfully, in making decisions about changes to meet these challenges. Such adaptation may require new ways of thinking and doing. In recent years, specialized literacy professionals have been asked to adapt in many ways. The emphasis on the Common Core State Standards (National Governors Association, 2010) and the focus on improving adolescent literacy have required them to learn more about disciplinary literacy and how to work with content area teachers. Also, because more and more emphasis has been given to improving teacher quality, especially in providing classroom reading instruction for all students, many literacy professionals find themselves having responsibilities for assisting teachers, both informally and formally. In fact, teacher performance evaluation literature suggests coaches may be involved in assessing teacher behaviors and then providing appropriate professional learning experiences for improvement (Goe, Biggers, \& Croft, 2012). Given these responsibilities, specialized literacy professionals need to be especially knowledgeable about how to work with school leadership to establish a climate and context conducive to change. At the same time, paradoxically, given the economic climate, many schools have eliminated coaching positions 
Specialized Literacy Professionals as Literacy Leaders

(Bean, Dole, Nelson, Belcastro, \& Zigmond, 2015). Often, reading specialists are then assigned leadership tasks that require them to analyze data with teachers, model, co-teach, and lead literacy reform efforts (Steinbacher-Reed \& Powers (2011/2012).

\section{Literacy Specialized Professionals May Not Be Prepared to Meet the Demands of Their Diverse Roles}

As mentioned above, fewer respondents held reading specialist certification in this study as compared to the 2002 study and even fewer coaches held reading specialist certification (19\%). We suspect the findings in this study reflect a nationwide trend. In the 2004 results of the School and Staffing Report (NCES), $81 \%$ or nine of ten respondents responsible for teaching reading in the schools indicated they had state certification as reading specialists. (Information about reading specialist certification in the more recent School and Staffing Questionnaires was not available). Several factors may account for this decrease. First, reading specialist certification may not be viewed as essential for those serving as coaches, especially instructional coaches. Second, states or districts, rather than requiring a state reading specialist certification, may be providing literacy-based professional development for specialized literacy professionals.

Although some minor distinctions between role-groups were offered in what they believed would better prepare them for their role, across all role-groups, respondents indicated they needed much more initial preparation for their leadership roles, including the following: working with adult learners, understanding of organizational systems and school change, working with the principal, and learning more about how to collaborate and coach more effectively. In other words, although most respondents felt they were prepared to handle instructional and assessment tasks, they did not feel prepared to serve as leaders or to work with adults. In several articles investigating the presence of leadership experiences in reading specialist certification programs, 
researchers found that about half of the participating universities included a leadership course in their programs (Quatroche \& Wepner, 2008; Wepner \& Quatroche, 2011). An important aspect of this study was the finding that respondents felt a need for ongoing mentoring, or for a network of colleagues who could meet and discuss issues as a means of helping each other address challenges in their schools.

\section{Implications}

The findings of this study have implications for many different audiences: literacy professionals themselves, those who prepare and hire them, researchers interested in investigating aspects of the roles, organizations that define the roles and provide professional development and support for literacy professionals, and policymakers responsible for developing regulations that form the foundation for quality performance.

\section{Defining the Role, Defining Leadership}

Given the findings that specialized literacy professionals have many different titles and serve in various roles, there is a need for better definitions describing these roles. For example, a recent Schools and Staffing survey distributed by the United States Department of Education (USDE, 2007-2008) distinguished simply between those who worked with students and those who worked with teachers; our evidence indicates that such a distinction is not enough. Literacy professional organizations, such as IRA and NCTE, in developing their standards documents, may need to consider clearer distinctions between roles and use those distinctions in establishing necessary competencies or qualifications for each role.

At the same time, leadership skills of specialized literacy professionals may need to be more fully defined and described. In the current Standards for Reading Professionals (IRA, 2010), statements tend to be broad (e.g., "demonstrate foundational knowledge of adult learning 
theories and related research about organizational change, professional development and school culture," Standard 6). The findings of this study indicated a need to unpack these statements in meaningful ways so that those preparing candidates have a clearer sense of what specific leadership activities should be included in a program.

\section{Preparation of Specialized Literacy Professionals: A Continuum of Responsibility}

Our findings about roles and responsibilities suggest that specialized literacy professionals need to be prepared to work with both teachers and students. We suggest that preparation programs consider the possibility of a developmental continuum in planning experiences for candidates in their programs. The continuum could include specific descriptions of initial, proficient, and advanced competencies, similar to the one described in Figure 3 for one of the IRA leadership standards, Working with Groups. Such continua would assist in course development, the sequencing of courses in a program, and in deciding which learning activities can serve as building blocks for more complex skills or knowledge.

\section{Ongoing Professional Learning}

This study provided strong evidence about the need for ongoing professional development for those serving as specialized literacy professionals, with respondents indicating the need for mentors and networks of colleagues to share challenges and successes. Such on-site, jobembedded professional learning can occur when specialized literacy professionals work in rolealike groups to discuss common issues or topics (e.g., how to use data more effectively to inform instruction, what data suggest about teaching or learning). Literacy leadership groups that include reading specialists, coaches, psychologists, etc., also provide an important source of professional learning, with each role-group learning from others. At the same time, novice 
specialized literacy professionals, regardless of responsibilities, might be assigned a mentor to serve as a source of support and provide feedback.

\section{Limitations}

Obtaining a large sample that would best represent the broad array of specialized literacy professionals was a difficult task. However, the snowball sampling approach (Nardi, 2003), did appear to address the limitation of the 2002 survey, in which participants were all members of the IRA. We received over 2,500 responses, and $44 \%$ of them stated they were not members of IRA while $90 \%$ did not hold membership in NCTE. Moreover, we received responses from all states as well as from professionals outside the United States. However, we acknowledge that respondents voluntarily completed the survey and may differ from non-volunteers. Nevertheless, the large sample size and broad geographic distribution gives us confidence in the results. Moreover, the field test conducted with specialized literacy professionals prior to launching the survey was helpful in identifying questions that may have been confusing to respondents. However, we acknowledge the limitations of surveys as a measurement procedure, recognizing they may result in conflicting conceptions and beliefs which cause participants to respond in contradictory or inconsistent ways (Eichelberger, 1989).

\section{Further Research}

The results of this study raise important questions for researchers interested in studying the work of literacy professionals in more depth. First, what are the indicators of success or effectiveness for each role? Second, what qualifications, especially knowledge, skills, and dispositions, related to leadership, do professionals in these roles require for success and how do they differ for those functioning at different levels (e.g., secondary, elementary)? Third, what conditions are necessary in schools for these professionals to work effectively as leaders? 
Finally, what activities or learning experiences in preparation programs best facilitate the development of leadership skills of those preparing to serve as specialized literacy professionals? Also, studies might be designed to provide for variations in how specialists function (e.g., intensity of involvement with teachers, model of coaching, school wide leadership efforts) and relate findings to measures of teacher performance or student learning.

\section{Conclusions}

In conclusion, the results of this study highlight the changes that have occurred in the role of specialized literacy professionals over the past 15 years as reported by the study participants. There are distinctions between the roles, especially between those of the reading specialist and literacy coach that call for changes in how these professionals are prepared and the qualifications they need to be effective in their positions. Results also indicate the importance of the leadership role for all specialized literacy professionals and are consistent with the current emphasis on shared leadership as an essential ingredient in school improvement. The results of this study indicate the roles of specialized literacy professionals are complex and require individuals serving in those roles have multiple skills, knowledge, and dispositions. Finally, results suggest the need for specialized literacy professionals to have more in-depth experiences focusing on leadership, not only in preparation programs, but also as an integral aspect of professional learning on the job. 


\section{References}

Bean, R. M. (2009). The reading specialist: Leadership for the classroom, school, and community. NY: The Guilford Press.

Bean, R. M., Cassidy, J., Grumet, J. V., Shelton, D., \& Wallis, S. R. (May, 2002).What do reading specialists do? Results from a national survey. The Reading Teacher, 55(8), 2-10.

Bean, R. M., Dole, J. A., Nelson, K. L., Belcastro, E., \& Zigmond, N. (2015). The sustainability of a national reading reform initiative in two states. Reading and Writing Quarterly, $31(1), 30-55$.

Bean, R. M., Draper, J. A., Hall, V., Vandermolen, J., \& Zigmond, N. (2010). Coaches and coaching in Reading First schools: A reality check. The Elementary School Journal, 11(2), 87-114.

Bean, R. M., \& Lillenstein, J. (2012). Response to Intervention and the changing roles of schoolwide personnel. The Reading Teacher, 65(7), 491-501.

Bean, R. M., Swan, A. L., \& Knaub, R. (2003). Reading specialists in schools with exemplary reading programs: Functional, versatile, and prepared. The Reading Teacher, 56(5), 446455.

Biancarosa, G., Bryk, A. S., \& Dexter, E. R. (2010). Assessing the value-added effects of literacy collaborative professional development on student learning. The Elementary School Journal, 111(1), 7-34.

Borman, G. D., Stringfield, S. C., \& Slavin, R. F. (2001). Title I: Compensatory education at the crossroads. Mahwah, NJ: Lawrence Erlbaum Associates. 
Specialized Literacy Professionals as Literacy Leaders

Briggs, D. A., \& Coulter, F. C. (1977). The reading specialist. In W. Otto, N. A. Peters, \& C. W. Peters (Eds.), Reading problems: A multidisciplinary perspective (pp. 215-236). Reading, MA: Addison Wesley Publishing.

Bright, E., \& Hensley, T. (2010). A study of the effectiveness of $K-3$ literacy coaches. Portsmouth, NH: National Reading Technical Assistance Center. Retrieved from www2.ed.gov/programs/readingfirst/support/effectivenessfinal.pdf

Bryk, A. S., Sebring, P. B., Alensworth, E., Luppescu, S., \& Easton, J. Q. (2010). Organizing schools for improvement: Lessons from Chicago. Chicago, IL: University of Chicago Press.

Camburn, E. M., Kimball, S. M., \& Lowenhaupt, R. (2008). Going to scale with teacher leadership: Lessons learned from a district-wide literacy coach initiative. In M. M. Mangin \& S. R. Stoelinga (Eds.), Effective teacher leadership: Using research to inform and reform (pp. 120-143), New York, NY: Teachers College Press.

Camburn, E., Rowan, B., \& Taylor, J. (2003). Distributed leadership in schools: The case of elementary scools adopting comprehensive school reform models. Educational Evaluation and Policy Analysis, 25(4), 347-373.

Carroll, K. (2007). Conversations with coaches: Their roles in Pennsylvania Reading First schools (Doctoral Dissertation, University of Pittsburgh). Retrieved from: http://d-scholarship.pitt.edu/7223/1/Carroll_ETD2007FINAL.pdf

Coburn, C., \& Woulfin, S. L. (2012). Reading coaches and the relationship between policy and practice. Reading Research Quarterly, 47(1), 5-32.

Dole, J. A. (2004). The changing role of the reading specialist in school reform. The Reading Teacher, 57, 462-471. 
Specialized Literacy Professionals as Literacy Leaders

Eichelberger, R. T. (1989). Disciplined Inquiry: Understanding and doing educational research. New York, NY: Longman.

Elish-Piper, L., \& L’Allier, S. (2010). Exploring the relationship between literacy coaching and student reading achievement in grades K-1. Literacy Research and Instruction, 49(2), 162-174.

Elish-Piper, L., \& L'Allier, S. (2011). Examining the relationship between literacy coaching and student reading gains in grades K-3. The Elementary School Journal, 112 (1), 83-106.

Elmore, R. F. (2000). Building a new structure for school leadership. The Albert Shanker Institute. Retrieved from www.ashanker-inst.org/Downloads/building.pdf.

Frost, S., \& Bean, R. M. (2006). Qualifications for literacy coaches: Achieving the gold standard. Retrieved from www.literacycoachingclearinghouse.org.

Galloway, E. P., \& Lesaux, N. K. (2014). Leader, teacher, diagnostician, colleague, and change agent: A synthesis of the research on the role of the reading specialist in this era of RTIbased literacy reform. The Reading Teacher, 67(7), 517-526.

Goe, L., Biggers, K., \& Croft, A. (2012). Linking teacher evaluation to professional development: Focusing on improving teaching and learning. Washington, DC: National Comprehensive Center for Teacher Quality.

Grierson, A. (2011). Walking the talk: Supporting teachers' growth with different professional learning. Paper presented at the annual conference of the American Educational Research Association, New Orleans, LA. 
Specialized Literacy Professionals as Literacy Leaders

L’Allier, S., Elish-Piper, L., \& Bean, R. M. (2010, April). What matters for elementary literacy coaching? Guiding principles for instructional improvement and student achievement. The Reading Teacher, 63(7), 544-555.

Ippolito, J. (2010). Three ways that literacy coaches balance responsive and directive relationships with teachers. The Elementary School Journal, 111(1), 164-190.

International Reading Association (2000). Teaching all children to read: The roles of the reading specialist. Newark, DE: Author.

International Reading Association. (2004). The role and qualifications of the reading coach in the United States [Position statement]. Newark, DE: Author. Available at: www.reading.org/General/AboutIRA/PositionStatements/ReadingCoachPosition.aspx

International Reading Association (2010). Standards for reading professionals--Revised 2010. Newark, DE: Author. Available at: http://www.reading.org/General/CurrentResearch/Standards/ProfessionalStandards2010/ ProfessionalStandards2010_Issues.aspx

Kern, D. (2011). 62 years of the pendulum's swing: The role of the reading specialist. The New England Reading Association Journal, 46(2), 67-72.

Lambert, L. (1998). Building leadership capacity in schools. Alexandria, VA: Association for Supervision and Curriculum Development.

Leithwood, K., \& Jantzi, D. (2008). Linking leadership to student learning: The contributions of leader efficacy. Educational Administration Quarterly, 44(54), 496-528.

Matsumura, L. C., Garnier, H. E., Correnti, R., Junker, B., \& Bickel, D. D. (2010). Investigating the effectiveness of a comprehensive literacy coaching program in schools with high teacher mobility. The Elementary School Journal, 111(1), 35-62. 
Specialized Literacy Professionals as Literacy Leaders

Nardi, P. M. (2003). Doing survey research: A guide to quantitative methods. Boston, MA: Allyn \& Bacon.

No Child Left Behind Act of 2001, P. L. 107-110, 20 U.S.C. $§ 6319$ (2001). National Governors Association, Center for Best Practices and Council of Chief State School Officers (2010). Common core state standards. Washington, DC: Author.

NVivo qualitative data analysis software (Version 10) (2010). [Computer Software]. QSR International Pty Ltd.: Melbourne, Australia.

Palmquist, M. E., Carley, K. M., \& Dale, T. A. (1997). Two applications of automated text analysis: Analyzing literary and non-literary texts. In C. Roberts (Ed.), Text analysis for the social sciences: Methods for drawing statistical inferences from texts and transcripts (pp. 171-189). Hillsdale, NJ: Lawrence Erlbaum Associates.

Powell, D., Diamond, K., \& Koehler, M. (2010). Use of a case-based hypermedia resource in an early literacy coaching intervention with pre-kindergarten teachers. Topics in Early Childhood Special Education. 29(4), 239-249.

Quatroche, D. J., \& Wepner, S. B. (2008). Developing reading specialists/literacy coaches as leaders: New directions for program development. Literacy Research and Instruction, 47(2), 99-115.

Scott, S. F., Cortina, K. S., \& Carlisle, J. F. (2012). Understanding coach-based professional development in Reading First: How do coaches spend their time and how do teachers perceive coaches' work? Literacy Research and Instruction, 51(1), 68-85.

Snow, C., Ippolito, J. \& Schwartz, R. (2006). What we know and what we need to know about literacy coaches in middle and high schools: A research synthesis and proposed research agenda. In Standards for middle and high school literacy coaches. Newark, DE: 
Specialized Literacy Professionals as Literacy Leaders

International Reading Association, 35-49. Retrieved from http://www.reading.org/resources/issues/reports/coaching.html

Stauffer, R. G. (1967). Change, but —. The Reading Teacher, 20, 474-499.

Steinbacher-Reed, C., \& Powers, E. (2011/ 2012). Coaching without a coach. Educational Leadership, 69(4), 68-72.

Supovitz, J., Sirinides, P., \& May, H. (2010). How principals and peers influence teaching and learning. Educational Administration Quarterly, 4(1), 31-56.

Taylor, B. M., Pearson, P. D., Peterson, D. S., \& Rodriguez, M.C. (2005). The CIERA school change framework: An evidence-based approach to professional development and school reading improvement. Reading Research Quarterly, 40(1), 40-69.

United States Department of Education. (2004). The schools and staffing survey. National Center for Educational Statistics. Retrieved from http://www.edpubs.org

United States Department of Education. (2007). The schools and staffing survey. National Center for Educational Statistics. Retrieved from www.nces.ed.gov/survey/sass

United States Department of Education. (2008). Reading First implementation evaluation: Final report. Washington, D.C.: Office of Planning, Evaluation and Policy Development, Policy and Program Studies Service. Retrieved from www.ed.gov/about/offices/list/opepd/ppss/inex.html

United States Department of Education. (2011-2012). The schools and staffing questionnaire. National Center for Educational Statistics. Retrieved from www.nces.ed.gov/questionnaire/sass

Vanderburg, M., \& Stephens, D. (2010). The impact of literacy coaches: What teachers value and how teachers change. The Elementary School Journal, 111(1), 141-163. 
Specialized Literacy Professionals as Literacy Leaders

Vescio,V., Ross, D., \& Adams, A. (2008). A review of research on the impact of professional learning communities on teaching practice and student learning. Teaching and Teacher Education, 24(1), 80-91.

Wepner, S. B., \& Quatroche, D. J. (2011). How are colleges and universities preparing reading specialist candidates for leadership positions in the schools? Reading Horizons, 51(2), 4. 
Specialized Literacy Professionals as Literacy Leaders

Table 1

Primary Responsibilities of Role-Groups

\begin{tabular}{|c|c|c|c|c|c|c|c|c|}
\hline \multirow[b]{2}{*}{$\begin{array}{l}\text { Primary } \\
\text { Responsibility }\end{array}$} & \multicolumn{2}{|c|}{$\begin{array}{l}\text { Instructional/ } \\
\text { Literacy } \\
\text { Coach }\end{array}$} & \multicolumn{2}{|c|}{$\begin{array}{l}\text { Reading } \\
\text { Teacher/ } \\
\text { Interventionist }\end{array}$} & \multicolumn{2}{|c|}{$\begin{array}{l}\text { Reading/ } \\
\text { Literacy } \\
\text { Specialist }\end{array}$} & \multicolumn{2}{|c|}{ Supervisor } \\
\hline & $n$ & $\%$ & $n$ & $\%$ & $n$ & $\%$ & $n$ & $\%$ \\
\hline $\begin{array}{l}\text { Coordinating } \\
\text { literacy } \\
\text { program } \\
\text { coaching }\end{array}$ & 503 & [2] & 17 & [3] & 24 & [3] & 19 & [18] \\
\hline $\begin{array}{l}\text { Teach } \\
\text { struggling } \\
\text { readers }\end{array}$ & 45 & [6] & 439 & [73] & 533 & [67] & 6 & [5] \\
\hline $\begin{array}{l}\text { Multiple } \\
\text { Responsibilities }\end{array}$ & 162 & [22] & 99 & [16] & 204 & [26] & 48 & [44] \\
\hline $\begin{array}{r}\text { Total } \\
\text { Respondents by } \\
\text { Role-groups }\end{array}$ & 723 & & 601 & & 798 & & 108 & \\
\hline
\end{tabular}

*Answered by 2,221 respondents 
Specialized Literacy Professionals as Literacy Leaders

Table 2

Rankings of Time Spent on Top Five Tasks by Role-Groups

\begin{tabular}{lllll}
\hline Group as & Instructional & Reading & Reading/Literacy & Supervisor \\
Whole & Coach/Literacy & Teacher/Interventionist & Specialist & \\
& Coach & & &
\end{tabular}

\begin{tabular}{|c|c|c|c|c|c|}
\hline Rank & & & Tasks & & \\
\hline 1 & $\begin{array}{l}\text { Instruct } \\
\text { Students }\end{array}$ & $\begin{array}{l}\text { Support } \\
\text { Teachers }\end{array}$ & Instruct Students & Instruct Students & $\begin{array}{l}\text { Support } \\
\text { Teachers }\end{array}$ \\
\hline 2 & $\begin{array}{l}\text { Analyze } \\
\text { Data }\end{array}$ & $\begin{array}{l}\text { Coach } \\
\text { Teachers }\end{array}$ & Assess Students & Assess Students & Analyze Data \\
\hline 3 & $\begin{array}{l}\text { Support } \\
\text { Teachers }\end{array}$ & Analyze Data & Analyze Data & Analyze Data & $\begin{array}{l}\text { Leadership } \\
\text { Activities }\end{array}$ \\
\hline 4 & $\begin{array}{l}\text { Assess } \\
\text { Students }\end{array}$ & $\begin{array}{l}\text { Leadership } \\
\text { Activities }\end{array}$ & Support Teachers & $\begin{array}{l}\text { Support } \\
\text { Teachers }\end{array}$ & $\begin{array}{l}\text { Facilitate } \\
\text { Teacher } \\
\text { Groups }\end{array}$ \\
\hline 5 & $\begin{array}{l}\text { Leadership } \\
\text { Activities }\end{array}$ & $\begin{array}{l}\text { Facilitate } \\
\text { Teacher } \\
\text { Groups }\end{array}$ & $\begin{array}{l}\text { Administrative } \\
\text { Tasks }\end{array}$ & $\begin{array}{l}\text { Administrative } \\
\text { Tasks }\end{array}$ & $\begin{array}{l}\text { Conduct } \\
\text { Workshops }\end{array}$ \\
\hline
\end{tabular}


Specialized Literacy Professionals as Literacy Leaders

Table 3

Coaching and Leadership Roles of Specialized Literacy Professionals

Coaching role

n $\%$

I have no responsibility for supporting the work of teachers.

$255 \quad[11.3]$

I am a coach and I spend about $1 / 2$ of my time supporting the work of

431

[19.1] teachers.

I am a coach and my major responsibility is supporting the work of teachers. 563

I am not identified as a coach, but I have a major role in supporting work of

276 teachers.

I am not identified as a coach, but I work informally in supporting the work $\quad 730$ of teachers.

*Answered by 2,255 respondents 
Specialized Literacy Professionals as Literacy Leaders

Table 4

Percentage of Respondents who Spent "A great deal" of Time on Specific Coaching and Leadership Activities

$\begin{array}{llll}\text { Instructional/ } & \text { Reading Teacher/ } & \text { Reading/Literacy } & \text { Supervisor } \\ \text { Literacy } & \text { Interventionist } & \text { Specialist } & \end{array}$

Coach

$\begin{array}{llll}\text { Conferring } & \text { Conferring } & \text { Serving on RtI team } & \text { Conducting Workshops } \\ {[57 \%]} & {[36.8 \%]} & {[42 \%]} & {[66 \%]}\end{array}$

Observing Serving on RtI Conferring [36\%] Conferring [51\%]

[55\%] Team [36.5\%]

Planning Planning with Planning [30\%] Observing [55\%]

[52\%] Teachers [26\%]

Conducting Modeling Co-teaching [28\%] Modeling [53\%]

Workshops [25\%]

[51\%]

$\begin{array}{llll}\text { Modeling } & \text { Observing } & \text { Serving as member of } & \text { Facilitating Professional Learning }\end{array}$

[51\%] [24\%] subject team [28\%] Community [51\%]


Specialized Literacy Professionals as Literacy Leaders

Table 5

Preparation that Would be Helpful to Respondents (Responses Categorized Using Standards in Preparing Specialized Literacy Professionals, IRA, 2010)

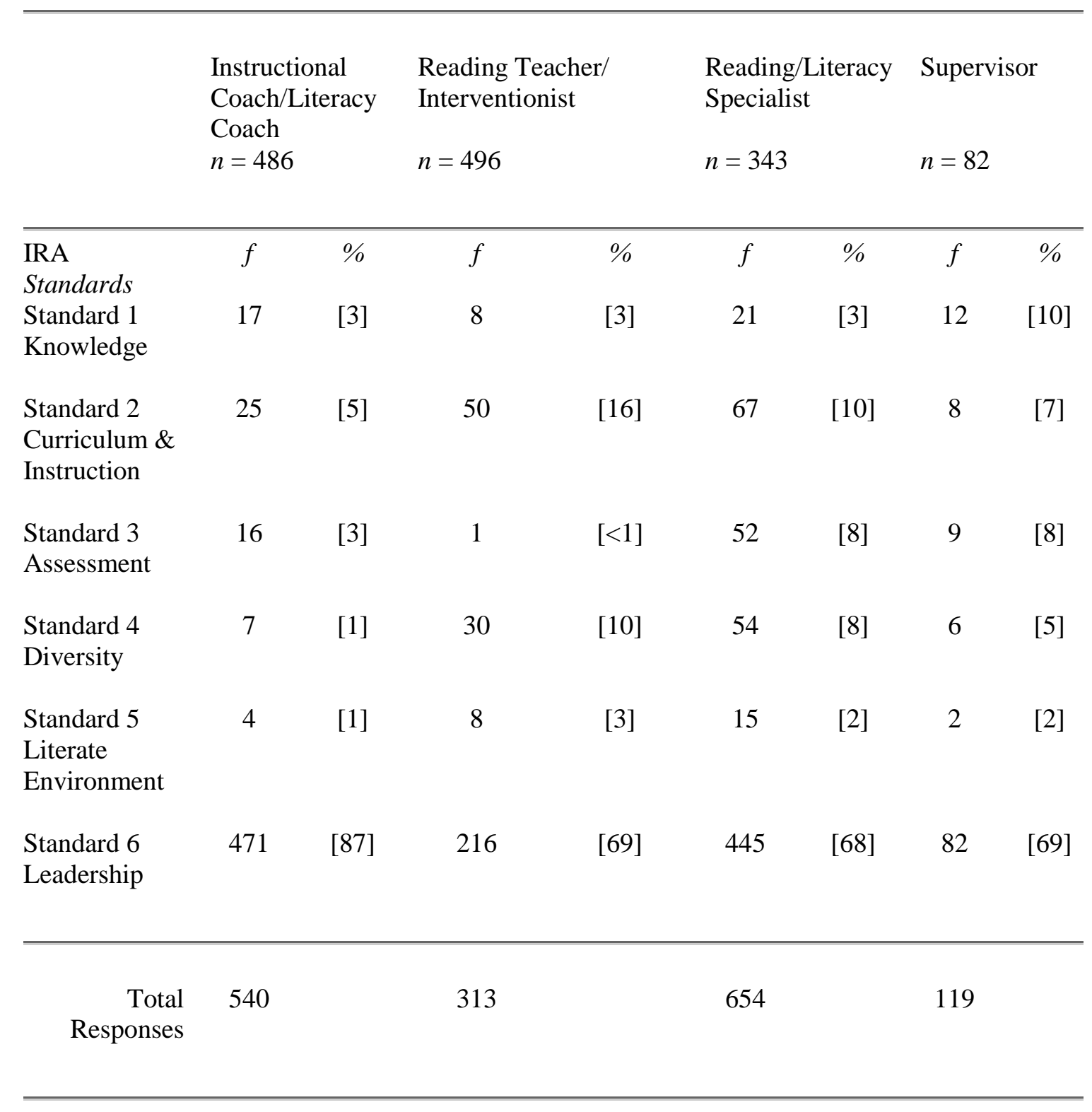

*Total of 1,407 respondents

**Total of 1,626 responses 
Specialized Literacy Professionals as Literacy Leaders

\begin{tabular}{|c|c|c|}
\hline & 2002 Study $(n=1,517)$ & 2014 Study $(n=2,531)$ \\
\hline Characteristics & & \\
\hline Certified as reading specialist & $90 \%$ & $53 \%$ \\
\hline Members of IRA & All & $56 \%$ \\
\hline $\begin{array}{l}\text { Source of Funding } \\
\text { District }\end{array}$ & $28 \%$ & $42 \%$ \\
\hline $\begin{array}{c}\text { Federal } \\
\text { Level of Work }\end{array}$ & $35 \%$ & $40 \%$ \\
\hline Primary & $81 \%$ & $*$ \\
\hline intermediate & $52 \%$ & $*$ \\
\hline elementary & $*$ & $52 \%$ \\
\hline middle school & $16 \%$ & $*$ \\
\hline high school & $8 \%$ & $*$ \\
\hline Middle/High School & $*$ & $21 \%$ \\
\hline Roles and Responsibilities & & \\
\hline Work with struggling readers & $90 \%$ & $98 \%$ \\
\hline Support Teachers & $84 \%$ & $89 \%$ \\
\hline Assess students & $99 \%$ & $70 \%$ \\
\hline
\end{tabular}

*Not available in this survey

Figure 1. Comparison of 2002 and Current Study 
Specialized Literacy Professionals as Literacy Leaders

\begin{tabular}{|c|c|c|}
\hline Role-Group & Major Responsibilities & $\begin{array}{c}\text { Minimal } \\
\text { Responsibilities }\end{array}$ \\
\hline $\begin{array}{l}\text { Instructional/literacy } \\
\text { coaches }(n=774)\end{array}$ & $\begin{array}{l}\text { Support teachers with } \\
\text { materials and ideas, } \\
\text { coach teachers, and } \\
\text { provide feedback to } \\
\text { them; work with school } \\
\text { leadership teams, and } \\
\text { facilitate teacher } \\
\text { groups }\end{array}$ & $\begin{array}{l}\text { Assess or instruct } \\
\text { students, coordinate } \\
\text { school reading } \\
\text { programs, provide } \\
\text { workshops, or } \\
\text { supervise other } \\
\text { professionals }\end{array}$ \\
\hline $\begin{array}{c}\text { Reading } \\
\text { teachers/interventionists } \\
(\mathrm{n}=707)\end{array}$ & $\begin{array}{l}\text { Assess and instruct } \\
\text { students; analyze data } \\
\text { for instructional } \\
\text { decision making }\end{array}$ & $\begin{array}{c}\text { Support teachers, } \\
\text { communicate with } \\
\text { parents, administrative } \\
\text { tasks }\end{array}$ \\
\hline $\begin{array}{l}\text { Reading/literacy } \\
\text { specialists ( } n=898)\end{array}$ & $\begin{array}{l}\text { Instruct students, } \\
\text { assess and analyzing } \\
\text { data; support teachers, } \\
\text { coordinate school } \\
\text { reading programs, } \\
\text { provide workshops, and } \\
\text { develop curriculum } \\
\text { ("jack-of-all trades") }\end{array}$ & $\begin{array}{l}\text { Support needs of } \\
\text { paraprofessionals and } \\
\text { grant writing endeavors }\end{array}$ \\
\hline Supervisors ( $n=142$ ) & $\begin{array}{l}\text { Coordinate school } \\
\text { reading programs, } \\
\text { curriculum } \\
\text { development, support } \\
\text { teachers with ideas and } \\
\text { materials, lead } \\
\text { workshops, coach } \\
\text { teachers }\end{array}$ & Grant writing \\
\hline
\end{tabular}

Figure 2. Summary of Major and Minimal Responsibilities of Specialized Literacy Professionals 
Specialized Literacy Professionals as Literacy Leaders

\begin{tabular}{|c|c|c|c|}
\hline Element & Initial & Proficient & Advanced \\
\hline $\begin{array}{l}\text { Leadership: Working } \\
\text { with Groups }\end{array}$ & $\begin{array}{l}\text { Understanding of } \\
\text { adult learning (effect } \\
\text { on group work) }\end{array}$ & $\begin{array}{l}\text { Understanding of } \\
\text { professional } \\
\text { development literature } \\
\text { and its effect on } \\
\text { teacher learning }\end{array}$ & $\begin{array}{l}\text { Understanding of } \\
\text { factors that influence } \\
\text { group work }\end{array}$ \\
\hline Options & $\begin{array}{l}\text { Observe and assess } \\
\text { effectiveness of group } \\
\text { meetings (leadership, } \\
\text { facilitation of } \\
\text { participation); } \\
\text { Lead study or book } \\
\text { group and assess } \\
\text { shared leadership, } \\
\text { accomplishment of } \\
\text { goals (reflect on your } \\
\text { role) }\end{array}$ & $\begin{array}{l}\text { Plan and conduct a } \\
\text { professional } \\
\text { development } \\
\text { workshop for your } \\
\text { colleagues } \\
\text { (Obtain feedback and } \\
\text { conduct a self- } \\
\text { reflection); } \\
\text { Meet with a grade } \\
\text { level team, addressing } \\
\text { a specific instructional } \\
\text { skill/strategy } \\
\text { (Obtain feedback and } \\
\text { conduct a self- } \\
\text { reflection) }\end{array}$ & $\begin{array}{l}\text { Lead a student data } \\
\text { meeting with teachers; } \\
\text { Facilitate professional } \\
\text { learning community } \\
\text { meeting in your } \\
\text { school; } \\
\text { (Obtain feedback and } \\
\text { conduct a self- } \\
\text { reflection) }\end{array}$ \\
\hline
\end{tabular}

Figure 3. Example of a Continuum for Leadership: Working with Groups 


\section{Appendix: Survey}

Role of the Reading Specialist/Literacy Coach

\section{SCHOOL/POSITION DEMOGRAPHICS:}

Job Title (drop down box) :

Titles would include: reading specialist; literacy coach; reading coach; reading facilitator; reading teacher; remedial reading teacher; interventionist; instructional support teacher; Title 1 teacher; other

State [drop down (dd)]:

Zip code

1. Is your position :

Full time

Part time

(a) If part time, other responsibilities include (check all that apply) Teaching

(b) Administrative

(c) Other

2. Is there a written job description for your position?

Yes

No

3. Funding source for position (check all that apply) school district

State

Federal (e.g., Title 1) 
grant funded

don't know

Other (please indicate below)

4. At how many schools do you work as a reading specialist/literacy coach? (dd) $1 ; 2 ; 3-4$; 5-6; more than 6

5. At what levels do you work? (check all that apply)

preschool __ Kindergarten Primary (grades 1-3) Intermediate (grades 4-5) middle school/junior high (grades 6-8) high school (grades 9-12)

6. If you work with students, what is your general workload? I don't work with students 10 or less ; 11-20 ;21-40 ; 41-60 ; more than 60

7. If you have coaching responsibilities, with how many teachers do you interact over the course of the year? I don't have coaching responsibilities 10 or less ; $11-$ 20 ; 21-30 ; 31-40 ; more than 40

\section{ROLE AS READING SPECIALIST/LITERACY COACH}

8. In your role as reading specialist/literacy coach, how would you rate each of the following responsibilities in terms of "emphasis" (the degree to which you spend time on these tasks)?

\begin{tabular}{|l|c|c|c|c|}
\hline & no time & $\begin{array}{l}\text { a little } \\
\text { time } \\
(1- \\
25 \%)\end{array}$ & $\begin{array}{l}\text { some } \\
\text { time } \\
(26- \\
60 \%)\end{array}$ & $\begin{array}{l}\text { great deal } \\
\text { of time } \\
\left(\begin{array}{l}\text { more } \\
\text { than } \\
60 \%)\end{array}\right.\end{array}$ \\
\hline Instructing students & $\mathrm{O}$ & $\mathrm{O}$ & $\mathrm{O}$ & $\mathrm{O}$ \\
\hline Assessing students & $\mathrm{O}$ & $\mathrm{O}$ & $\mathrm{O}$ & $\mathrm{O}$ \\
\hline Supporting teachers with materials, ideas, etc. & $\mathrm{O}$ & $\mathrm{O}$ & $\mathrm{O}$ & $\mathrm{O}$ \\
\hline
\end{tabular}




\begin{tabular}{|l|c|c|c|c|}
\hline $\begin{array}{l}\text { Coaching teachers by modeling, observing } \\
\text { and providing feedback }\end{array}$ & $\mathrm{O}$ & $\mathrm{O}$ & $\mathrm{O}$ & $\mathrm{O}$ \\
\hline Curriculum development & $\mathrm{O}$ & $\mathrm{O}$ & $\mathrm{O}$ & $\mathrm{O}$ \\
\hline $\begin{array}{l}\text { Coordinating the school reading program } \\
\text { (e.g., arranging scheduling, grouping, } \\
\text { selecting materials) }\end{array}$ & $\mathrm{O}$ & $\mathrm{O}$ & $\mathrm{O}$ & $\mathrm{O}$ \\
\hline $\begin{array}{l}\text { Working with a designated leadership team at } \\
\text { the school (principal, other specialized } \\
\text { personnel, teacher leaders, etc.) }\end{array}$ & $\mathrm{O}$ & $\mathrm{O}$ & $\mathrm{O}$ & $\mathrm{O}$ \\
\hline $\begin{array}{l}\text { Facilitating teacher groups (e.g., grade level, } \\
\text { department, data teams) }\end{array}$ & $\mathrm{O}$ & $\mathrm{O}$ & $\mathrm{O}$ & $\mathrm{O}$ \\
\hline Working with the RtI team & $\mathrm{O}$ & $\mathrm{O}$ & $\mathrm{O}$ & $\mathrm{O}$ \\
\hline Conducting workshops (PD) for teachers & $\mathrm{O}$ & $\mathrm{O}$ & $\mathrm{O}$ & $\mathrm{O}$ \\
\hline $\begin{array}{l}\text { Participating in community of practice } \\
\text { activities (e.g., facilitating study groups, } \\
\text { discussion of instructional practices) }\end{array}$ & $\mathrm{O}$ & $\mathrm{O}$ & $\mathrm{O}$ & $\mathrm{O}$ \\
\hline $\begin{array}{l}\text { Supporting or supervising paraprofessionals } \\
\text { or volunteers }\end{array}$ & $\mathrm{O}$ & $\mathrm{O}$ & $\mathrm{O}$ & $\mathrm{O}$ \\
\hline Analyzing data & $\mathrm{O}$ & $\mathrm{O}$ & $\mathrm{O}$ & $\mathrm{O}$ \\
\hline $\begin{array}{l}\text { Administrative tasks (paperwork, arranging } \\
\text { materials, etc.) }\end{array}$ & $\mathrm{O}$ & $\mathrm{O}$ & $\mathrm{O}$ & $\mathrm{O}$ \\
\hline $\begin{array}{l}\text { Non-reading related tasks (subbing, class } \\
\text { coverage, other duties) }\end{array}$ & $\mathrm{O}$ & $\mathrm{O}$ & $\mathrm{O}$ & $\mathrm{O}$ \\
\hline $\begin{array}{l}\text { Communicating with or providing outreach to } \\
\text { parents }\end{array}$ & $\mathrm{O}$ & $\mathrm{O}$ & $\mathrm{O}$ & $\mathrm{O}$ \\
\hline Grant writing & $\mathrm{O}$ & $\mathrm{O}$ & $\mathrm{O}$ \\
\hline Your own professional development & $\mathrm{O}$ & $\mathrm{O}$ \\
\hline
\end{tabular}

Other Tasks: (please specify):

9. In your role as reading specialist/literacy coach, how would you rate each of the following responsibilities in terms of importance to your success as a reading specialist/literacy coach?

\begin{tabular}{|l|r|r|r|r|}
\hline & $\begin{array}{l}\text { no } \\
\text { time } \\
(0 \%)\end{array}$ & $\begin{array}{l}\text { a little } \\
\text { time } \\
(1- \\
25 \%)\end{array}$ & $\begin{array}{l}\text { some } \\
\text { time } \\
(26- \\
60 \%)\end{array}$ & $\begin{array}{l}\text { great deal } \\
\text { of time } \\
\text { (more } \\
\text { than } \\
60 \%)\end{array}$ \\
\hline Instructing students & $\mathrm{O}$ & $\mathrm{O}$ & $\mathrm{O}$ & $\mathrm{O}$ \\
\hline Assessing students & $\mathrm{O}$ & $\mathrm{O}$ & $\mathrm{O}$ & $\mathrm{O}$ \\
\hline Supporting teachers with materials, ideas, etc. & $\mathrm{O}$ & $\mathrm{O}$ & $\mathrm{O}$ & $\mathrm{O}$ \\
\hline $\begin{array}{l}\text { Coaching teachers by modeling, observing and } \\
\text { providing feedback }\end{array}$ & $\mathrm{O}$ & $\mathrm{O}$ & $\mathrm{O}$ & $\mathrm{O}$ \\
\hline Curriculum development & $\mathrm{O}$ & $\mathrm{O}$ & $\mathrm{O}$ & $\mathrm{O}$ \\
\hline
\end{tabular}




\begin{tabular}{|l|r|r|r|c|}
\hline $\begin{array}{l}\text { Coordinating the school reading program (e.g., } \\
\text { arranging scheduling, grouping, selecting } \\
\text { materials) }\end{array}$ & $\mathrm{O}$ & $\mathrm{O}$ & $\mathrm{O}$ & $\mathrm{O}$ \\
\hline $\begin{array}{l}\text { Working with a designated leadership team at the } \\
\text { school (principal, other specialized personnel, } \\
\text { teacher leaders, etc.) }\end{array}$ & $\mathrm{O}$ & $\mathrm{O}$ & $\mathrm{O}$ & $\mathrm{O}$ \\
\hline $\begin{array}{l}\text { Facilitating teacher groups (e.g., grade level, } \\
\text { department, data teams) }\end{array}$ & $\mathrm{O}$ & $\mathrm{O}$ & $\mathrm{O}$ & $\mathrm{O}$ \\
\hline Working with the RtI team & $\mathrm{O}$ & $\mathrm{O}$ & $\mathrm{O}$ & $\mathrm{O}$ \\
\hline Conducting workshops (PD) for teachers & $\mathrm{O}$ & $\mathrm{O}$ & $\mathrm{O}$ & $\mathrm{O}$ \\
\hline $\begin{array}{l}\text { Participating in community of practice activities } \\
\text { (e.g., facilitating study groups, discussion of } \\
\text { instructional practices) }\end{array}$ & $\mathrm{O}$ & $\mathrm{O}$ & $\mathrm{O}$ & $\mathrm{O}$ \\
\hline $\begin{array}{l}\text { Supporting or supervising paraprofessionals or } \\
\text { volunteers }\end{array}$ & $\mathrm{O}$ & $\mathrm{O}$ & $\mathrm{O}$ & $\mathrm{O}$ \\
\hline Analyzing data & $\mathrm{O}$ & $\mathrm{O}$ & $\mathrm{O}$ & $\mathrm{O}$ \\
\hline $\begin{array}{l}\text { Administrative tasks (paperwork, arranging } \\
\text { materials, etc.) }\end{array}$ & $\mathrm{O}$ & $\mathrm{O}$ & $\mathrm{O}$ & $\mathrm{O}$ \\
\hline $\begin{array}{l}\text { Non-reading related tasks (subbing, class } \\
\text { coverage, other duties) }\end{array}$ & $\mathrm{O}$ & $\mathrm{O}$ & $\mathrm{O}$ & $\mathrm{O}$ \\
\hline $\begin{array}{l}\text { Communicating with or providing outreach to } \\
\text { parents }\end{array}$ & $\mathrm{O}$ & $\mathrm{O}$ & $\mathrm{O}$ & $\mathrm{O}$ \\
\hline Grant writing & $\mathrm{O}$ & $\mathrm{O}$ & $\mathrm{O}$ & $\mathrm{O}$ \\
\hline $\begin{array}{l}\text { Your own professional development } \\
\text { Task: (Please spcify) }\end{array}$ & $\mathrm{O}$ & $\mathrm{O}$ \\
\hline
\end{tabular}

Other Tasks: (Please specify)

10. Which of these titles best describes your primary responsibility? [dd]

(a) Teacher of students who are experiencing difficulty with reading

(b) Literacy Coach (responsible for supporting instructional efforts of teachers)

(c) Coordinator or manager of reading program

(d) I have multiple and equal responsibilities: (please specify)

Other: 


\section{Instruction}

11. Do you instruct students? [dd]

Yes __ No (if you answer no, please skip to item 16)

12. Identify the model that best describes where you deliver instruction. [dd] all pullout all in-class combination of pull-out and in-class

13. To what extent do you plan instruction for the students you teach with the classroom teacher(s)? [dd]

never

sometimes

to a great extent

always

14. Do the students whom you teach receive reading instruction from other personnel in the school and if so, from whom? (check all that apply) [dd] classroom teacher paraprofessional special educator volunteer no, I am the students' sole reading instructor.

15. How would you describe the students you instruct? [dd] (check all that apply)

students experiencing difficulties with reading

students who are not experiencing difficulties with reading

\section{Assessment}

16. How involved are you in each of the following:

\begin{tabular}{|l|c|c|c|c|}
\hline & $\begin{array}{l}\text { Not at all } \\
\text { Involved }\end{array}$ & Little involved & $\begin{array}{l}\text { Somewhat } \\
\text { involved }\end{array}$ & $\begin{array}{l}\text { Very } \\
\text { involved }\end{array}$ \\
\hline Screening students & O & O & O & O \\
\hline
\end{tabular}




\begin{tabular}{|l|c|c|c|c|}
\hline Progress monitoring & $\mathrm{O}$ & $\mathrm{O}$ & $\mathrm{O}$ & $\mathrm{O}$ \\
\hline Diagnostic assessment & $\mathrm{O}$ & $\mathrm{O}$ & $\mathrm{O}$ & $\mathrm{O}$ \\
\hline $\begin{array}{l}\text { Analyzing data for } \\
\text { instructional decision } \\
\text { making }\end{array}$ & $\mathrm{O}$ & $\mathrm{O}$ & $\mathrm{O}$ & $\mathrm{O}$ \\
\hline $\begin{array}{l}\text { Analyzing data for whole } \\
\text { school reform }\end{array}$ & $\mathrm{O}$ & $\mathrm{O}$ & $\mathrm{O}$ & $\mathrm{O}$ \\
\hline $\begin{array}{l}\text { Response to Intervention } \\
\text { efforts }\end{array}$ & $\mathrm{O}$ & $\mathrm{O}$ & $\mathrm{O}$ & $\mathrm{O}$ \\
\hline $\begin{array}{l}\text { Analyzing data with } \\
\text { teachers to plan } \\
\text { instruction }\end{array}$ & $\mathrm{O}$ & 0 & & \\
\hline
\end{tabular}

\section{Supporting Work of Teachers}

17. If you are responsible for supporting the work of teachers in any way, how would you describe your role? (choose one) [dd] identified as a coach and my major responsibility is supporting the work of teachers identified as a coach and I spend about $1 / 2$ of my time supporting the work of teachers not identified as a coach but I have a major role in supporting teachers and their instruction not identified as a coach but I work informally with classroom teachers to support their instructional efforts

I have no responsibility for supporting the work of teachers. If you responded that you have no responsibility for supporting the work of teachers, please go to item 24 .

other (please specify below).

18. If you support teachers in your role, what types of preparation did you receive before you assumed the position? (check all that apply)

university or college preparation as reading specialist/coach

online preparation as a literacy or instructional coach 
Specialized Literacy Professionals as Literacy Leaders

attended professional conferences

Read professional books about coaching

attended coaching workshops describe

none

Other:

19. What was the nature of the PD that you have received? (check all that apply) emphasis on process of coaching

emphasis on content of instruction (vocabulary, comprehension, etc.)

emphasis on building a professional learning community in school

Other

20. Who makes decisions about the PD that you receive? (Check all that apply) the leadership of the school

the leadership of the district

I do

21. As an individual responsible for supporting the work of teachers, which of the following best describes the nature of that work? [dd]

I work with teachers who ask me to work with them

I have responsibilities for working with all the teachers in the school, but make choices about how and with whom I work

- I have responsibility for working with all teachers in the school, and it is expected that I will see or coach all teachers.

Other: 
22. As an individual supporting the work of teachers, please rate the emphasis you give to each of the following activities:

\begin{tabular}{|l|c|c|c|c|}
\hline & Not at all & Little & Somewhat & Great deal \\
\hline 1.Modeling for teachers & $\mathrm{O}$ & $\mathrm{O}$ & $\mathrm{O}$ & $\mathrm{O}$ \\
\hline $\begin{array}{l}\text { 2.Observing and providing } \\
\text { feedback }\end{array}$ & $\mathrm{O}$ & $\mathrm{O}$ & $\mathrm{O}$ & $\mathrm{O}$ \\
\hline 3.Co-teaching & $\mathrm{O}$ & $\mathrm{O}$ & $\mathrm{O}$ & $\mathrm{O}$ \\
\hline 4.Planning with teachers & $\mathrm{O}$ & $\mathrm{O}$ & $\mathrm{O}$ & $\mathrm{O}$ \\
\hline $\begin{array}{l}\text { 5.Using the observation cycle } \\
\text { (pre-conference; observing; } \\
\text { post-conference) }\end{array}$ & $\mathrm{O}$ & $\mathrm{O}$ & $\mathrm{O}$ & $\mathrm{O}$ \\
\hline $\begin{array}{l}\text { 6.Conferring with teachers about } \\
\text { identified problems (problem- } \\
\text { solving) }\end{array}$ & $\mathrm{O}$ & $\mathrm{O}$ & $\mathrm{O}$ & $\mathrm{O}$ \\
\hline $\begin{array}{l}\text { 7.Facilitating grade-level } \\
\text { meetings }\end{array}$ & $\mathrm{O}$ & $\mathrm{O}$ & $\mathrm{O}$ & $\mathrm{O}$ \\
\hline $\begin{array}{l}\text { 8.Facilitating subject area } \\
\text { meetings }\end{array}$ & $\mathrm{O}$ & $\mathrm{O}$ & $\mathrm{O}$ & $\mathrm{O}$ \\
\hline $\begin{array}{l}\text { 9.Serving as a member of grade } \\
\text { level team }\end{array}$ & $\mathrm{O}$ & $\mathrm{O}$ & $\mathrm{O}$ & $\mathrm{O}$ \\
\hline $\begin{array}{l}\text { 10.Serving as a member of a } \\
\text { subject area team }\end{array}$ & $\mathrm{O}$ & $\mathrm{O}$ & $\mathrm{O}$ & $\mathrm{O}$ \\
\hline $\begin{array}{l}\text { 11. Serving as member or } \\
\text { facilitating the RtI team }\end{array}$ & $\mathrm{O}$ & $\mathrm{O}$ & $\mathrm{O}$ & $\mathrm{O}$ \\
\hline $\begin{array}{l}\text { 12. Conducting workshops for } \\
\text { teachers }\end{array}$ & $\mathrm{O}$ & $\mathrm{O}$ & $\mathrm{O}$ & \\
\hline $\begin{array}{l}\text { 13. Facilitating professional } \\
\text { learning community in the } \\
\text { school }\end{array}$ & $\mathrm{O}$ & $\mathrm{O}$ & \\
\hline
\end{tabular}

23. Looking at the following activities, please rank from 1-5 (1 being most influential) those items you believe are most important for effecting teacher change.

\begin{tabular}{|l|}
\hline 1.Modeling for teachers \\
\hline $\begin{array}{l}\text { 2.Observing and providing } \\
\text { feedback }\end{array}$ \\
\hline 3.Co-teaching \\
\hline 4.Planning with teachers \\
\hline $\begin{array}{l}\text { 5.Using the observation cycle } \\
\text { (pre-conference; observing; } \\
\text { post-conference) }\end{array}$ \\
\hline $\begin{array}{l}\text { 6.Conferring with teachers about } \\
\text { identified problems (problem- }\end{array}$ \\
\hline
\end{tabular}




\begin{tabular}{|l|}
\hline solving) \\
\cline { 1 - 1 } 7.Facilitating grade-level \\
meetings
\end{tabular}

\section{School Climate/Professional Development}

24. Please answer the following questions about the climate in the school where you spend most of your time.

\begin{tabular}{|l|r|r|c|c|}
\hline & $\begin{array}{l}\text { Not } \\
\text { at all }\end{array}$ & A little & $\begin{array}{l}\text { Somewha } \\
\mathrm{t}\end{array}$ & $\begin{array}{l}\text { To a } \\
\text { great } \\
\text { extent }\end{array}$ \\
\hline $\begin{array}{l}\text { There is a common vision for improving the } \\
\text { literacy learning of students. }\end{array}$ & $\mathrm{O}$ & $\mathrm{O}$ & $\mathrm{O}$ & $\mathrm{O}$ \\
\hline are high expectations for students. & $\mathrm{O}$ & $\mathrm{O}$ & $\mathrm{O}$ & $\mathrm{O}$ \\
\hline Teachers enjoy teaching in this school. & $\mathrm{O}$ & $\mathrm{O}$ & $\mathrm{O}$ & $\mathrm{O}$ \\
\hline $\begin{array}{l}\text { Teachers help each other by sharing ideas and } \\
\text { materials. }\end{array}$ & $\mathrm{O}$ & $\mathrm{O}$ & $\mathrm{O}$ & $\mathrm{O}$ \\
\hline $\begin{array}{l}\text { The principal provides the leadership necessary } \\
\text { to make the school a place of learning for both } \\
\text { teachers and students. }\end{array}$ & $\mathrm{O}$ & $\mathrm{O}$ & $\mathrm{O}$ & $\mathrm{O}$ \\
\hline $\begin{array}{l}\text { Students have respect for the school and for the } \\
\text { teachers in the school. }\end{array}$ & $\mathrm{O}$ & $\mathrm{O}$ & $\mathrm{O}$ & $\mathrm{O}$ \\
\hline
\end{tabular}

25. To what extent does the school in which I work exemplify characteristics of a professional learning community?

\begin{tabular}{|l|l|l|l|l|}
\hline & Not At All & A Little & Somewhat & To a great \\
\hline
\end{tabular}


Specialized Literacy Professionals as Literacy Leaders

\begin{tabular}{|l|l|l|l|l|}
\hline & & & & extent \\
\hline $\begin{array}{l}\text { There are shared } \\
\text { values and } \\
\text { norms. }\end{array}$ & & & & \\
\hline $\begin{array}{l}\text { There is a focus } \\
\text { on student } \\
\text { learning. }\end{array}$ & & & & \\
\hline $\begin{array}{l}\text { There are } \\
\text { opportunities for } \\
\text { reflective } \\
\text { dialogue among } \\
\text { teachers. }\end{array}$ & & & & \\
\hline $\begin{array}{l}\text { There are } \\
\text { opportunities for } \\
\text { collaboration } \\
\text { among } \\
\text { educators at the } \\
\text { school. }\end{array}$ & & & & \\
\hline $\begin{array}{l}\text { Teaching is } \\
\text { made public. }\end{array}$ & & & & \\
\hline
\end{tabular}

26. Who is responsible for evaluating your performance in the school? (Check all that apply) [dd]

_principal

__ reading coordinator or supervisor

__ district coordinator or supervisor

Other: Please identify 
27. Is some sort of performance rating system used for evaluating your work? Yes No

If yes, how closely aligned to your job responsibilities is that performance rating system?

not at all

to some extent

to a great extent

28. Please rate your perceptions about the following:

\begin{tabular}{|l|c|c|c|c|}
\hline & $\begin{array}{l}\text { Not } \\
\text { Adequate }\end{array}$ & $\begin{array}{l}\text { Somewhat } \\
\text { Adequate }\end{array}$ & Adequate & $\begin{array}{l}\text { Highly } \\
\text { Adequate }\end{array}$ \\
\hline $\begin{array}{l}\text { How well prepared were you for the position } \\
\text { you currently hold? }\end{array}$ & $\mathrm{O}$ & $\mathrm{O}$ & $\mathrm{O}$ & $\mathrm{O}$ \\
\hline $\begin{array}{l}\text { How adequate is the system for evaluating your } \\
\text { performance? (Does it provide you with the } \\
\text { feedback required to improve your } \\
\text { performance?) }\end{array}$ & $\mathrm{O}$ & $\mathrm{O}$ & $\mathrm{O}$ & $\mathrm{O}$ \\
\hline
\end{tabular}

29. What sort of preparation would have been helpful to you in preparing you for your position? [comments box (cb)]

30. What are three major challenges you face in your position (please describe): [cb]

31. What are the most positive aspects of your position, e.g., What do you enjoy most about your role? [cb]

32. What do you need to be successful in your role? 
33. Additional comments: [cb]

PERSONAL DEMOGRAPHICS: (This information is extremely important as it will enable us to obtain knowledge about the experiences and education of those who serve in these roles.)

34. Select the most accurate answers from the drop down menu Gender: [dd] female male

Ethnicity:[dd] African American Asian American Caucasian Hispanic Other

Highest Degree Held: [dd] Bachelor's Master's Doctorate

Other:

Certification/license: (select all that apply) $[\mathrm{dd}]$ classroom teacher reading specialist reading teacher literacy coach special education ELL teacher ; reading supervisor other:

Other certifications/licenses:

35. How many years have you served in your current role (including this year)? (use drop down box) $0-2 ;-3-5 ; 6-8 ; 9-12 ; 13-15$; more than 15

36. Before serving in a specialist/coach role, were you a classroom teacher, and for how long did you teach? Select from the following:[dd] was never a classroom teacher 1-5 years; 6-10 years; 11-15 years: 16-20 years; ___ more than 20 years.

37. At what grade levels did you teach: pre-school ; kindergarten elementary ; middle school ; high school

38. Undergraduate major and/or concentration:_(use dd box): elementary; secondary (provide academic discipline here - English, Math, social studies, Science, other); special education; reading/literacy; 
39. Graduate major and/or concentration: use dd box: Reading Education; Language Arts; (use from \#33 above)

40. I belong to the following professional organizations (check all that apply): local reading council

State Reading Association

International Reading Association

National Council of Teachers of English

National Education Association

American Federation of Teachers

Other: Identify:

41. What professional development (PD) have you received since you became a reading specialist/coach? (check all that apply)

_university or college preparation

_online preparation

_attended professional conferences

_district workshops

attended coaching workshops describe the focus of the workshops:

none

other: please specify)

Would you be willing to participate in a follow-up phone interview? [dd] _ yes __ no If yes, please indicate name and email address. 
Would you be willing to have your principal respond to a short survey about the role of the reading specialist/coach in your school? [dd] __ Yes __ No

If yes, please ask the principal if you could provide us with his/her name and email address. Include below.

Thank you for responding to this questionnaire. If you would like a summary of our results, please indicate and provide your name and email address.

Name

Email address: 